\title{
ADVOCATING FOR THE PROTECTION OF RIGHTS OF CHILDREN AND WOMEN IN NIGERIA: AN APPRAISAL
}

\author{
Nneka Umejiaku * \\ Department of Commercial and Property Law, Faculty of Law Nnamdi Azikiwe University, Nigeria, \\ Email: nnekaumejiaku@gmail.com
}

(Received: August 2020; Accepted: October 2020; Published: November 2020)

\begin{abstract}
The protection of children and women in Nigeria is very critical because their integration in every sphere is a precedent to the growth and development of nations. However, they face diverse discrimination and violence because they are very vulnerable. The object of this study is to examine the rights of children and women by x-raying the various legal and institutional frameworks that provide for their rights, as well as dangers posed by taking their rights for granted. The work analyses factors that inhibit their protection and proffers a viable solution. In this paper, we adopt the doctrinal and empirical methods of legal research. The study discovers that despite a legion of legislation, children and women are exposed to many factors such as legal, social, economic, and obnoxious cultural practices. Further, the work reveals that inherent lapses are visible in our legal framework particularly the 1999 Constitution (as amended), Child's Rights Act and other relevant legislation. Accordingly, the work recommends for the eradication of factors that promote child and women abuse and review of relevant laws. The work further recommends for a serious synergy between the government and non-governmental organizations for the protection of children and women.
\end{abstract}

Keywords: Advocacy, Protection, Rights, Women and Children's Right.

\section{Introduction}

The human rights of women and children are germane in recent times because of their critical role in the development of nations. This work argues that despite the establishment of numerous legal frameworks at the national, regional and domestic level, the human rights of women and children are still fraught with violence. Women experience systemic violence; at pre-birth, women suffer from sexselective abortion, as an infant, they suffer from female infanticide, neglect i.e. lack of health care, poor nutrition; as a child, they suffer female genital mutilation; as

\footnotetext{
* Corresponding author: Nneka Umejiaku.E-mail: nnekaumejiaku@gmail.com.
} Commons - Attribution 4.0 International - CC BY 4.0) which permits unrestricted use, distribution, and reproduction in any medium, provided the original author and source are credited. 
adolescence, they are forced into prostitution, trafficking, early marriage and rape. As an adult, they are exposed to intimate partner violence like assault, battery and as an elder, she is confronted with widowhood abuse such as wife inheritance and denial of spouse property [1]. Hence, the work advocates for urgent remedy by the Government to eradicate pending challenges such as the recent global pandemic (corvid 19), poor economic situation, armed conflict, an explosion in information technology, and obnoxious cultural practices that are inimical to women and children. Accordingly, the author proposes to arrive at definite findings. Firstly, whether women and children are indeed objects of human rights. Secondly, whether there are still factors that violate their rights despite the legion of legislation. Thirdly, whether the government can address various lapses inherent in our legal framework in order to alleviate the plight of children and women. Finally, whether the judiciary can be more proactive in enforcing their rights.

\section{The Concept of Rights}

The word right has been defined to mean "that which is proper under the law. Something that is due to a person by just claim... legal guarantee, a legally enforceable claim that another will do or will not do a given act, a recognized and protected interest the violation of which is wrong, a breach of duty that infringes ones rights" [2]. The interest, claim, or ownership that one has intangible or tangible property [3]. According to Osita Eze, human rights represent, demands or claims which individual or groups make on society, some of which are protected by law and have become part of lex lata, while other remain aspiration to be attained in the future [4]. While Prof. Umozurike defines it, as claims, which are invariably supported by ethics and which should be supported by law, made on society especially on its official managers, by individuals or groups on the basis of their humanity. They apply regardless of race, color, sex and other distinction and may not be withdrawn or derived by governments, people or individuals. They are those rights which every individual claim or aspires to enjoy irrespective of his color, race, religion station in life. Accordingly, from the above definitions, one can easily infer that human rights are rights that inure in man because he is human. Hence, all human beings including women and children are universally recognized as objects of human rights. These rights include rights to personal liberty, rights to private and family life, the right to freedom of thought, conscience, and religion etcetera.

In expounding the difference between human rights and fundamental human rights, the court in Ransom kuti v. A.G Federation [5] held that only rights that are spelled out in the Constitution of various states are recognized as fundamental rights, while other rights remain mere rights. Hence, the Constitution has stipulated rights that must be recognized, enforced and enjoyed by women and children. 
Umejiaku, N., (2020)

Further, in 1977 Carel Vasak, introduced the concept of generation into the corpus of human rights and divided them into three major categories namely first, second and third-generation rights [6]. The first generational rights are the civil and political rights of individuals. While the second-generation rights include economic, social, and cultural rights and provide for the material wellbeing of the individual, it, therefore, requires the state to necessarily put in place the material conditions upon which economic social, and cultural rights can be enjoyed. Hence, whereas the civil and political rights have become constitutionally entrenched and recognized, as having an absolute character of "inalienability" and "enforceability" the economic and social rights have no such constitutional status [7]. The third generation of solidarity rights comprises of right to peace, development, good and healthy environment. These rights relate to the organic and corporate existence and working of the society. They include the right to a safe and healthy environment, the right to development, and the right to share in the common heritage of mankind. These rights are still in the process of progressive development [8].

\section{The Development of Children's Right and Women's Right}

The development of a child's rights can be traced to the 19th century. A nation began to recognize the human rights of children, Jean Valles attempted to establish a league for the protection of child's rights in the aftermath of the Paris Committee [9]. Consequently, many international and regional instruments sprang up advocating for the protection of children because of their disability. They aver that children should be given special treatment to enable them to develop their abilities and reach their maximum potentials. This is to ensure equality of everyone as regards their welfare and the enjoyment of their human rights and fundamental freedoms. The major concern of the international community is to protect children from issues that violate their rights such as child labor, the sale of children, child prostitution, child abuse, juvenile delinquency, and juvenile justice. One of the first treaties which specifically dealt with children as a group was the international agreement for the suppression of the white slave traffic signed at Paris on the 18th of May 1904. The international protection of children's rights received a further impetus in 1919, with the setting up of the League of Nations and the International Labour Organization [10]. The International Conference adopted at its first session, the minimum age (industry) convention and had since adopted numerous convention and recommendations concerning the minimum age for employment in diverse activities as well as hours of and conditions of work. Within a decade of its funding, the League of Nations had adopted the International Convention for the Suppression of Trafficking in Women and Children 1921 [11]. In 1922 Enlantyne Jebb, pleaded by a Memorandum addressed to Save the Children International Union, in Geneva, for the creation of a code for children. By February 28, 1924, 
the code, known as the Declaration of Geneva, was signed and tagged the Declaration [12] of the rights of the child. The Declaration provided for the protection of the child in every sphere. Particularly, it provided five basic principles which include the following principles: firstly, that each child must be provided with the requisite means for his or her normal development, both materially and spiritually. Secondly, the hungry child must be fed. Thirdly, that the child must be the first to receive relief. Fourthly, that the child must be protected from every form of exploitation and finally that a child must be raised in the consciousness that his talents must be devoted to the service of men [13]. While women's rights can be traced to the 17th century. The best known early writing on the subject were those of with respect to women's right, Mary Wollstonecraft in her book, A Vindication of the Rights of Women [14], feminist declaration of independence. 'Wollstonecraft dared to take the liberal doctrine of inalienable human rights, a doctrine which was inflaming patriots on both sides of the Atlantic and assume these rights for her own sex" [15]. Accordingly, many writers in the 18th and 19th agitated for equality and raised series of questions about the need to recognize women's sexuality and their autonomous sexual desire, the possibility of equality in marriage and domestic relationship, and the importance of education for girls and rational motherhood. Undoubtedly, the demand for, an end to sexual oppression, recognition of women in the late eighteenth century became a springboard for modern feminism and, ipso facto women's movement [16]. In 1866, John Stuart Mill, championed women emancipation via suffrage campaign, of course, women were at the forefront of the suffrage campaign, establishing women's suffrage journal and suffrage campaign committees across Great Britain and Ireland in the late 1860s, and it became an avenue for continuous agitation for property and legal rights of married women, until the, Married Women's Property Act of 1882 was enacted [17]. The London National society for women's suffrage, women's freedom League and National Union societies for equal citizenship amongst others, continued the struggle until limited suffrage was achieved in 1917 and later in 1928, the Equal Franchise Act, gave women the right to vote on the same terms as men. Other legislative development gradually followed suit to shatter other institutional barriers, for example, the removal of the Sex Discrimination Act in 1929. This resulted in the admission of women to the legal profession and earn degrees in universities amongst several legislative developments in that era which, later, women were to enjoy and take for granted in many of the British colonies of Africa and beyond [18].

In Nigeria, women's struggle is connected to their quest to be emancipated from colonial rule. The activities of women which include Aba Women (anti-tax) riot of 1929 as well as the Egba women rebellion of 1947 is illustrative [19]. Furthermore, the organization of Nigerian women at the national level is fairly 
Umejiaku, N., (2020)

recent with the formation of 1953, of the Federation of Nigeria Women Societies (FNWSA). This was followed in 1959 with the formation of the National Council of Women Societies (NCWS) as an umbrella organization of women. The high point in the women's struggle was the establishment of the National Commission for Women (1989) which culminated into ministry in a response to call for the creation of the women's ministry preparatory meetings held in Dakar in 1994. Consequently, many legislations were also established for the protection of women and children such as the Convention on Elimination of Discrimination Against Women (CEDAW), that is specific to women, while the Convention on the Rights of the (Child) CRC is specific to children. Apart from these two legislations, there are many which, some, would be discussed in this work.

\section{Legal framework for Protection of Children and Women \\ 4.1. Convention on the Rights of the Child}

This Convention [20] entrenches four basic principles such as non-discrimination, the best interest of the child, the right to life, survival, and development of the child [21]. It contains protection rights which include prevention from abuse and neglect in several of its articles. It provides that state parties shall take all appropriate legislative administrative, social, and educational measures to protect the child, from all forms of physical abuse [22]. It also provides that state parties should recognize the rights of every juvenile consistent with the promotion of the child's sense of dignity and worth for the human rights and fundamental freedom of others and which takes into account the child's age and the desirability of promoting the child's reintegration and the child's assuming a constructive role in society [23]. In order to combat the problems associated with the involvement of children in armed conflict, and of sale of children, child prostitution, and child pornography, two additional optional protocols were adopted, the optional protocol to Convention on the Rights of the Child on the Sale of Children, Child Prostitution and Child Pornography (OP-CRC-SC) [24] and the Optional Protocol to the Convention on the Rights of the Child on the Involvement of Children in Armed Conflict (OpCRC-AC) [25]. The Optional Protocol on the Convention on the Rights of the Child on the Sale of children (OP-CRC-SC) extends the measures that states parties should undertake in order to guarantee the protection of the child, from numerous exploitation [26]. It recognizes that vulnerable groups, including girl children, are at greater risk of sexual exploitation and that children are disproportionately represented among the sexually exploited, the optional protocol underscored the fact that the elimination of the sale of children, child prostitution, and child pornography [27] will be facilitated by adopting a holistic approach, addressing the contributing factors, including underdevelopment, poverty, economic disparities, inequitable socio-economic structure, dysfunction families, 
lack of education, urban-rural migration, gender discrimination irresponsible adult sexual behavior, harmful traditional practices, armed conflicts, and trafficking in children [28].

\subsection{Child's Right Act}

The Act, recognizes all the rights of children as fundamental, restores their confidence and self-esteem, and improves their status. It demands that in all actions concerning the child, his best interest, welfare, and well-being must be paramount. Consequently, appropriate legislative and administrative measures concerning the best interest of the child are articulated in part one of the Act. Further, it provides for the enjoyment of physical, mental, and spiritual health. It mandates the reduction of child mortality rates and the provision of necessary medical assistance and health care services [29]. It prohibits child labor and provides that no child shall be subjected to any forced or exploitative labor or employed to work in any capacity except where he is employed by members of his family on the light of an agricultural horticultural or domestic character or required in any case, to lift carry or move anything heavy as to be likely to adversely affect his physical or mental, development [30]. Further, no person shall expose or involve a child in the production or trafficking of narcotic drugs or psychotropic substances [31]. Furthermore, the Act protects the child against all forms of sexual exploitation or abuse or recruitment into any of the branches of the armed forces of the Federal Republic of Nigeria. Additionally, it prohibits the use of corporal punishment of whatsoever form or nature, abolished the death penalty, and make the age of 18 years to be the age below which a child cannot be subjected to the adult criminal process, but can only be subjected to the child justice administration process. It also prohibits the joint trial of children with adults under any circumstance and also makes provision for the separation of children from adults in detention in all circumstances.

\subsection{Convention on the Elimination of All Forms of Discrimination Against Women.}

CEDAW reaffirms faith in fundamental human rights, in the dignity and worth of the human person and in the equal rights of men and women. It reiterates that state parties to the International Covenants on Human Rights have the obligation to ensure the equal rights of men and women to enjoy all economic, social, cultural, civil and political rights. Considerably the international conventions concluded under the auspices of the United Nations and the specialized agencies promoting equality of rights of men and women. However, it notes that despite the various instruments intensive discrimination against women continues to exist. It recalls that discrimination against women violates the principles of equality of rights and 
Umejiaku, N., (2020)

respect of human dignity, is an obstacle to the participation of women, on equal terms with men, in the political, social, economic and cultural life of their countries. It hampers the growth of the prosperity of society and the family and reduces the contribution of women in the services of their countries and humanity. Concerned that in situations of poverty, women have the least access to food, health, education, training and opportunities for employment and other needs. Article 2 reiterates that state parties condemn discrimination against women in all its form, agree to pursue by all appropriate means and without delay, a policy of eliminating discrimination against women and, undertake [32] firstly to embody the principle of equality of men and women in their national Constitutions or other appropriate legislation, if not yet incorporated therein and to ensure, through law and other appropriate means, the practical realization of this principle. Secondly, to adopt appropriate legislative and other measures, including sanctions where appropriate, prohibiting all discrimination against women. Thirdly, to establish legal protection of the rights of women on an equal basis competent national tribunals and other public institutions for the protection of women against discrimination. Fourthly, to refrain from engaging in any act or practice of discrimination against women and to ensure that public authorities and institutions shall act in conformity with this obligation. Finally, to take all appropriate measures to eliminate discrimination against women by any person, organization, or enterprise [33]. and to take all appropriate measures including legislation, to modify or abolish existing laws regulations customs, and practices which constitute discrimination against women [34]. Further, State Parties shall take in all fields, in particular in the political social-economic, and cultural field, all appropriate measures, including legislation to ensure the full development and advancement of women for the purpose of guaranteeing them the exercise and enjoyment of human rights and fundamental freedom on a basis of equality with men.

\subsection{African Charter on the Rights and Welfare of the Child}

The Act [36] provides that states shall take all appropriate measures to eliminate harmful cultural practices affecting the welfare, dignity, growth and development of children particularly with respect to those customs and practices prejudicial to their health. Hence, child marriage and the betrothal of girls and boys shall be prohibited and effective, action, including legislation, shall be taken to specify the minimum age of marriage to be 18 years and make registration of all marriages in an official registry compulsory [37]. Further, it protects the child from armed conflict and provides that children shall not take a direct part in hostilities and refrain in particular, from recruiting any child [38]. Furthermore, it protects refugee children from violence [39]. 


\subsection{African Charter on Human and Peoples Right.}

The Act recognizes that every individual shall be entitled to the enjoyment of the rights and freedoms recognized and guaranteed in the present Charter without distinction of any kind such as race, ethnic group, color, sex language, religion, political, or any other opinion, national and social origin fortune, birth or any states [40]. Hence, the State Party, shall eliminate every discrimination against women and also ensure the protection of the rights of women and children as stipulated in international declaration and Conventions. Protocol to prevent, suppress, and punish trafficking in persons has been established, for especially women and children, supplementing the United Nations Convention Against Transnational Organized Crime. The purpose of this protocol is to prevent and combat trafficking in persons, paying particular attention to women and children. To also protect and assist the victims of such trafficking, with full respect for their human rights and promote cooperation among state parties to meet those objectives [41].

\subsection{Convention on the Elimination of all Forms of Discrimination Against Women}

This Convention [42] is convinced that the establishment of the economic order based on equity and justice will contribute significantly towards the promotion of equality between men and women. It, therefore, urges state parties to use measures aimed at acceleratory de facto equality between men and women [43]. Furthermore, measures to modify the social and cultural patterns of conduct of men and women with a view to achieving the protection of women and children should be encouraged.

\subsection{The 1999 Constitution (as amended)}

The 1999 Constitution makes a copious provision for the protection of women and children respectively. Particularly, the chapter (iv) provides the right to life [44] and development which is the foundational rights upon which other rights are predicated. Undoubtedly, this right is considered as the most precious gift to every citizen, so that non should be deprived of his life. Hence, the government has the duty to provide security for children and women even in times of armed conflict, in order to prevent an act of genocide, apart from that, the Constitution provides the right to dignity of the human person, and aver that children and women are not to be subjected to any form of torture or be exposed to inhuman or degrading treatment. Further, the Constitution enumerates the acts which will be regarded as violating the dignity of the person of the child and torture as used in the Constitution, could be physical as in physical brutalization of the human person or mental as in agony or worry [45]. While inhuman treatment could be a situation of deliberately causing severe pain, suffering physical or mental which are not 
Umejiaku, N., (2020)

justifiable in law [46]. With respect to the child, it is argued that corporal punishment or life imprisonment as sentences imposed on a child constitute inhuman treatment. Apart from these rights, the Constitution provides for personal liberty, non-discrimination, and freedom of expression which guarantees the right to children and women to hold an opinion, receive, and impact knowledge. Furthermore, in addition to all these fundamental rights, the Constitution in its chapter (ii) makes provisions for what is called fundamental objections and directive principles for, what it calls fundamental objectives and directive principles of state policy, which are geared towards the promotion and protection of the rights of Nigerian citizens particularly women and children [47]. Under this heading, the Constitution imposes a constitutional obligation on all tiers of government to observe the fundamental objectives relating to the socio-political, economic, educational, and cultural issues with respect to the security and welfare of women in Nigeria [48].

\section{Factors that Exacerbate Violence Against Women and Children 5.1. Non Implementation of Relevant Laws 5.1.1. Non-adoption of Child Right's Act}

Non-adoption of the Child's Right Act by many States in Nigeria has negated the rights of children in Nigeria, for instance, the Act provides that the child shall only be subjected to only juvenile justice. However, many are subjected to the ordinary court system, while many are subjected to customary and sharia laws. The Act [49] provides for the establishment of specialized children unit, with the sole aim of training them in child matters for the protection of children, who come under juvenile justice. However, empirical research [50] reveals that many Police Stations, do not have specialized children unit, hence they lack the expertise in handling child matters, for instance, research carried out in Police Institution shows, that $41.70 \%$ of child matters are not charged to courts, while $25 \%$ of child cases are not represented by counsel, hence exposing them to harm [51] .Children are kept with adult inmates which exposes them to harm. Apart from the police, the dearth of the custodial institution has hampered the rights of children and many children are exposed to sexual violence by adult prison inmates. Consequently, lack of Family Court, as a result of this challenge has also affected the Court. In C.O.P v Friday Idehen [52], the accused was sentenced to 6 months imprisonment with hard labor however on appeal, the High Court of Benin observed that "if the Magistrate had taken account of his youth he would have persuaded that the accused is adolescent youth who needed correction rather than punishment". Also in the case of Oyeneye v. C.O.P, the court sentenced a child to four years' imprisonment but on appeal the High Court observed that the lower court did not give these matters due consideration as required by the relevant authorities and that 
4 years' jail sentence for a young offender is more likely to harden than reform and it is therefore against the public interest. The study advocates that serious measures should be taken to alleviate the plight of children in this regard.

\subsubsection{Unenforceability of Chapter (ii) of the 1999 Constitution}

Another problem is the reluctance of the government to make Chapter (ii) enforceable has made many women and children be exposed to violence. Thus, in the case of Archbishop Olubunmi Okogie vs the Lagos State [53] the court, clearly established that fundamental objectives and directive principles are not justiciable. In fact, the Court of Appeal held that the combined effect of sections 13,17 , and $\sec 6$ (6) of the Constitution ousts the jurisdiction of the court from entertaining any matter that is contained in Chapter(ii) of the Constitution. Nigeria should make the Chapter (ii) of the Constitution justiciable so that women and children will enjoy their rights as held in jurisdictions like India, South Africa, and other African States. In Government of the Republic of South Africa v Groothoom [54] the court held that making these provisions unenforceable, is unconstitutional. Their interconnectedness needs to be taken into account in interpreting the socioeconomic rights, and in particular in determining whether the state has met its obligations in terms of them. There is a serious nexus between Chapter (ii) and Chapter (iv) of (1999) Constitution because the civil and political rights cannot be achieved without enforcement of economic social and cultural rights. According to Okoeguale, Chapter (ii)should be adopted for the purpose of implementing human rights standards in its interventions and in providing technical assistance [55]. It is therefore advocated that Nigeria's Government should shift all the rights in Chapter (ii) to Chapter (iv) in order to actualize the rights of women and children in Nigeria.

\subsubsection{Lapses in Relevant Laws}

Various lapses in the relevant legal framework have jeopardized the rights of women and children, for instance, there are diverse definition with respect to the definition of the child [56]. Hence, the conflict exposes them to diverse violence. Apart, from that, incorporation of corporal punishment has inflicted harm on children and women respectively for instance, in Sharia states, haddi lashing is still carried out, because Sharia Legal Code, despite the fact that it violates the Constitution [57]. The Zimbabwean Supreme Court in Stphen Ncube \& Ors v The State Court was invited to interpret section 15 (1) of the Country Constitution which is in pari material with section 34 (1) of the Nigerian Constitution, 1999. The court in declaring corporal punishment unconstitutional held it to be not only inherently brutal and cruel, it is relentless in its severity and contrary to the 
Umejiaku, N., (2020)

traditional humanity practiced by almost the whole of the civilized world being incompatible with the evolving standards of decency.

\subsection{Corona Virus (Covid 19)}

With the recent global pandemic, children and women are exposed to more abuse and violation of their human rights. Currently, more than one million children are out of school in a bid to control the Coronavirus. Even though many resorts to online banking but the majority are not connected to the internet, hence their future would be jeopardized if nothing is done to protect them. With the majority of children staying at home, many would be exposed to early marriage, teenage pregnancy, domestic violence. While many will engage in child labor to argument the dearth of funds due to harsh economic conditions [58]. It is therefore advocated that State Parties should act urgently to establish measures that would alleviate the plight of children and women.

\subsection{Armed Conflict}

Armed conflicts are torrid times for women and children. More than 2 million children have been killed in armed conflict, with 6 million injured or paralyzed for life, armed complicit has orphaned more than 1 million children. In Nigeria, the Boko Haram insurgence has displaced many women and children and has exposed them to diverse violence such as rape and other forms of abuse [59]. Nadulovu, UNFPA country representative postulates that the number of births recorded among internally displaced persons in Nigeria would hit 60,000 by the end of 2015 [60]. Despite the enactment of the terrorism act 2011 Boko Haram activities have not been curbed in Nigeria [61].

United Nations expressing, its deep concern over the suffering of women and children belonging to the civilian population who in a period of emergency and armed conflict in the struggle for peace, self-determination national liberation, and independence are two often consequently suffer serious harm. Bearing in mind the need to provide special protection of women and children belonging to the civilian population and bombings on the civilian population, inflicting incalculable and children, who are the most vulnerable members of the population shall be prohibited, and such acts shall be condemned [62]. All efforts shall be made by states involved in armed conflicts, a military operation in foreign territory or military operation in territories still under colonial domination to spare women and children from the ravages of war [63]. All the necessary steps shall be taken to ensure the prohibition of measures such as persecution, torture, punitive measures, degrading treatment, and violence, particularly against that part of the civilian population that consists of women and children [64]. Further, all forms of repression, cruel and inhuman treatment of women and children including 
imprisonment, torture, shooting mass arrests collective punishment destruction of dwelling, and forcible eviction should be curtailed.

\subsection{Harmful Cultural and Traditional Practices}

In Nigeria, cultural and traditional practices hamper the rights of women and children such practices include son preference, child marriage, female genital mutilation, etc. With respect to son preference, women and female children are often discriminated against on grounds of sex particularly with respect to succession. In Muojekwe v Muojekwe, the Court declared "Oliekpe" custom discriminatory for denying women access to their father's property. Further, the court held that, that law failed the repugnancy doctrine and therefore null and void. The basis of the decision was that it is a clear case of discrimination and inapplicable against a girl-child and offends section 42 of the Constitution that upholds the principle of equality. Despite the sound judgment, the Supreme Court in the case of Mojekwu v Iwuchukwu [65] reversed the decision in Mojekwu v Mojekwu [66] and held that the Oli-ekpe is not repugnant customary practice. However, in determining a similar question bordering on the right of the girl-child to the estate of her deceased father in the recent decision of the supreme court in the case of Ukeje v Ukeje [67], Rhoodes Vivour JSC held its discriminatory customary law and void as it conflicts with section 42 (1) and (2) of the Constitution. The same position was restated by the Supreme Court in the case of Anekwe Anor v Nweke[68] where the court struck down the practice that disinherits women from accessing her late husband's estate, because she had no male child for the husband, the court held inter alia that," it baffles one to still find in civilized society, which cherishes equality between the sexes, a practice that disentitles the woman (wife in this matter) to inherit from her late husband's estate simply because she has no 'male child' from the husband". The above highlight is goo but courts should be more proactive in upholding the rights of women and children so that they will enjoy their fundamental human rights.

\subsection{Illegitimate Children}

Illegitimate children are denied access to inheritance and are always treated as a second class citizen. This practice was struck down by the court [69] in the case of Okoli v Okoli [70] were the Court held that, the phrase illegitimate children used to describe children born out-of-wedlock has been rendered illegal and unconstitutional. Hence, any child born out of wedlock can employ the provision of the Nigerian Constitution as a shield from being discriminated against or subjected to any disability. 
Umejiaku, N., (2020)

\subsection{Female Genital Mutilation}

Another cultural practice that impedes the rights of women and children is Female Genital Mutilation. FGM is defined by the World Health Organization (WHO, M1994) as "all procedures which involve partial or total removal of the external female genitalia, and (or injury to the female genital organs), whether for cultural or any other nontherapeutic reason [71]. This act is carried out at a very young age, where the possibility of getting consent from the female children is nil, and by so doing, violate the fundamental human rights of the victim's right to life, bodily integrity, health, and sexuality, as many girls die, or develop severe health complications because of these operations [72].

\subsection{Child Marriage}

Child Marriage hampers the rights of children because it prevents them from giving their consent in the marriage. The court in Osamawoyin v Osamawoyin [73] held that the consent of the bride-to-be was a condition precedent to the marriage under Bini Customary law, and because no such consent was given, there was indeed no subsisting customary law marriage at the time the respondent married the petitioner. The same decision was held by several courts in a different jurisdiction, to show that consent is a condition precedent to a valid marriage [74] Child marriage cripples the development and growth of the child in every sphere, hence the CEDAW encourages states parties to take all appropriate measures to modify the social and cultural pattern of conduct of men and women, to achieve the elimination of prejudices and customary practices that affect the girl child negatively.

\subsection{Trafficking in Persons}

Trafficking in person is one of the criminal fastest growing businesses in the world, which, results in serious breaches of the dignity of trafficked persons. It targets children and women because they are vulnerable. The establishment of the National Agency for the prohibition of trafficking in persons and other related matters (NAPTIP) and its awareness campaigns including the works of a nongovernmental organization in the country also targeted at public enlightenment to prevent trafficking in human beings has not eradicated human trafficking. This is because Nigeria is a transit and country of destination for trafficked persons, hence despite, a legion of laws [75] on the protection of human persons, women and children are lured due to the harsh economic situation in the country to other nations where they are used for sexual exploitation, pornography organ harvesting [76]. Trafficking in persons is regarded as organized crime because it involves most of the time, more than one criminal acting in concert to engage in the unlawful trading of human beings, sometimes crossing through several borders 
with accomplices [77]. In AG-Federation v Eze Osagie where the accused was charged for committing an offense contrary to sections 23, 24 and 19 of the law of Nigeria, the Court held that he was liable for the offense of trafficking and punished him accordingly. In the case of Attorney-General of the Federation v, Mrs. Sarah Okoya [78] the accused, a female, was charged with the deceitful inducement of some six girls aged between 19 to 23 to travel with her from Uromi in Edo state, Nigeria to Cotonou, in the Republic of Benin contrary to section 19 (1) and 16 of TIP 2003. On trial, she denied the allegation but the honorable court disbelieved her and sentenced her to serve a term of imprisonment for a total period of 36 months with hard labor. With the greatest respect, the punishment is not commensurate with the offense committed because many of them are not remorseful and oftentimes go back to it because it is a lucrative business. Consequently, the study advocates for stiffer penalties, to curb this social menace.

\section{Conclusions}

The work reveals that despite a legion of laws, at the international, regional and national sphere that the human rights of women and children still fraught with many factors. These factors are legal, economic, social and political in nature. With respect to legal factors, the work observed that there are lapses inherent in our laws that jeopardize the rights of women and children and calls for urgent review in order to protect the rights of women. Apart from legal, factor, the study discovers that the retrogressive economic situation caused by corvid 19 has negatively affected the rights of women and children. Hence, the work calls on the Government to take serious action to alleviate the plight of women and children.

\section{Recommendations}

(1) Review of relevant legislation like the 1999 Constitution, Child's Right Act, Evidence Act etcetera for effective protection of women and children.

(2) Implementation and adoption of the Child's Right Act by all the States in Nigeria.

(3) Integration of women and children in different spheres of the society for maximum growth and development of the nation.

(4) Establishment of viable measures for the eradication of factors that are inimical to women and children, particularly obnoxious cultural practices that impede their rights.

(5) Synergy between the Government and non-Government organizations should be encouraged in order to alleviate the plight of children and women in Nigeria.

(6) Creation of viable facilities should be enhanced particularly custodial institutions should be built while dilapidated ones should be refurbished. 
Umejiaku, N., (2020)

Advocating for the protection of rights of children and women in Nigeria: An appraisal

(7) Legislative oversight should be encouraged. This will enable Legislators to monitor whether enacted laws are enforced, where they are not enforced they go back to the drawing table to improve the law.

(8) Creation of awareness on the protection of women and children is very imperative for their protection.

\section{Acknowledgments}

The author thanks the anonymous reviewers and editor for their valuable contribution.

\section{Funding}

This research received no specific grant from any funding agency in the public, commercial, or not-for-profit sectors.

\section{Author Contributions}

The entire article was written by Nneka Umejiaku.

\section{Disclosure Statement}

The author has not any competing financial, professional, or personal interests from other parties.

\section{References}

1. Adedokun, A.A., (2014). An overview of Child Justice Administration under Child Right Legislation in Nigeria, The Nigerian Law Journal Vol. 17, NO. 1.

2. Agbo, C.U., (2019). Incidence of "Woman to Woman" Marriage at Customary Law and the Challenge of Same-Sex Marriage Prohibition in Nigeria: A Contextual Overview Journal of Contemporary Customary \& Sharia Law Issue in Nigeria (JOCCSLIN), Vol.1.

3. Arinze-Umobi, C., Domestic Violence Against Women in Nigeria: A legal anatomy, (Onitsha: Folmech Printing \& Publishing C0. Ltd Nigeria).

4. Arowolo, G.A, (2010). Oversight Functions of the Legislature an Instrument for Nation Building, Nnamdi Azikiwe University, Journal of International Law and Jurisprudence, Vol. 1 Sept.

5. Ettor, K.S, (2016). Legal FrameWork for the Right of Child in Nigeria and the Imperative Question of Enforceability, Kogi State University Law Journal, Vol. 8.

6. Ezeilo, J.N, Women Law \& Human Rights: Global and National Perspectives (Nigeria: Acena Publisher 2011).

7. Ogwo, B., (2015). Terrorism Act 2011 and the Boko Haram Activities in Nigeria: An Appraisal, University of Jos Law Journal, Vol. 10, No. 1.

8. Okeceguale, H., (2017). Applying Human Rights-Based Approach to Criminal Justice reforms in Nigeria, Abuad Journal of Public and International Law (AJPIL), Vol. III, No. 1. 
9. Olarmde, E.S., Agbais, M.N., (2017). Succession Rights and Legitimation in Nigeria: An Appraisal of the Status of Children Born outside a subsisting marriage. ABUAD Journal of Public and International Law (AJPIL) Vol.III, No. 1

10. Umejiaku, N.O., (2018). Strengthening Legal Frame Work on Domestic Violence in Nigeria Juvenile Justice Administration in Nigeria (Nigeria IFEVIC Printing and Publishing Co, 2018).

11. Yebisi, E.F., Fabamise, A., (2017). Sexual Harassment and the Law: Manifest Social Trajectories in the Nigerian Organizational Environment ABUAD Journal of Public and International Law (AJPIL) Vol. III, No 1.

\section{Notes}

[1] N O Umejiaku, Strengthening Legal Frame Work on Domestic Violence in Nigeria: Strategies for implementation Journal African of Constitutional and Administrative Law (AJCAL) Vol.2, 2018, p. 69.

[2] C. Arinz-Umobi, Domestic Violence Against Women in Nigeria, A Legal Anatomy (Nigeria: Folmech Printing Company 2008) p. 8.

[3] Ibid.

[4] Umozurike U.O, The African Charter on Human \& People Right (Nigeria: The Hague Martinus Nijhoff Publishers 1979) p. 4.

[5] Karel vasak A 30-year struggle UNESCO COUPRIER (1977) pg. 29 in A K Ahmed The Law and Child Rights in Nigeria,(Nigeria: Malthouse Press Limited 2015).

[6] B.A Adbulmum, The law and Childs Right in Nigeria, (Nigeria: Malthouse Press Ltd,2015).p. 9.

[7] Ibid.

[8] Ibid.

[9] Ibid.

[10] J.N. Ezeilo op.cit.

[11] League of Nations, Treaty Series vol. LX 253415.

[12] Ibid.

[13] A.K. Ahmed op cit. p.25.

[14] Barbara Canie, English 1780-1980 (Oxford: Oxford University Press, 1997), from J. N, Ezeilo Women Law \& Human Rights Global and National Perspectives. [15] Ibid.

[16] J.N Ezeilo, women Law \& Human Rights Global and National Perspectives (Nigeria: Acena Publishers 2011) p. 33.

[17] Ibid.

[18] Ibid.

[19] Ibid.

[20] United Nation Convention on the right of the Child 1989.

[21] Ibid article 16.

[22] Article 19.

[23] Ibid. 
Umejiaku, N., (2020)

Advocating for the protection of rights of children and women in Nigeria: An appraisal

[24] Adopted 25th May 2000 and came into force on 18th January 2002. Nigeria's government ratified it on September 8, 2000. See General Assembly Resolution.

[25] Ibid.

[26] Adopted 25th May 2000 and came into force on 18th January 2002. Nigeria's government ratified it on September 8, 2000. See General Assembly Resolution.

[27] Also adopted on May 25, 2000, but this protocol came into force on February 12, 2002, Nigeria government is equally a state party to this protocol which is ratified also on September 8, 2000.

[28] The preamble to the OP-CRC-SC-noted the need for this optional protocol in order to further achieve the purposes of the convention on the Rights of the Child, and the implementation of provisions $1,11,21,32,33,34,35 \& 36$.

[29] Sec. 1 \& 2 of CRA.

[30] Ibid.

[31] Sections 27-32.

[32] A Convention on the Elimination of All Forms of Discrimination Against.

[33] Women Adopted by the United Nations General Assembly Resolution 34, 18 on 18 December 1979 (1249 U.N.T.S. 13) and it entered force on 3 September 1981.

[34] Article 2.

[35] Article 3.

[36] African Charter on the Rights of the Child.

[37] Adopted and opened for signature 11th July 1990 and it entered into force 29 November 1999.

[38] Article 21.

[39] Article 22.

[40] Article 2.

[41] Article 2.

[42] Adopted Assembly Resolution 34/180 General Assembly Resolution 34/180 on 18 December 1979 (1249 U.N.T.S. 13) and it entered into force on 3 September 1981.

[43] Article 4.

[44] 1999 Constitution sec 33.

[45] Mogaji v Board of Customs \& Excise (1982) 2 NCL

[46] Ibid.

[47] A K Ahmed op cit 57.

[48] NM Jamo, Civil and Human Rights under the 1999 Nigerian Constitution Need for some Amendment. In A K Ahmed op cit.

[49] Child's Right Act 2003 section 207.

[50] Umejiaku N O Ph.D., dissertation (2017) research in Nigeria police reveals that many police stations do not have specialized Children Unit for proper administration in child matters.

[51] Ibid.

[52] (Unreported) B/BCA/71, High Court Benin.

[53] (1981), 2 NCLR, 337.

[54] (2001), 36 WRN137. 
[55] H. Okoeguale Applying Human Rights-Based Approach to Criminal Justice Reforms in Nigeria, Abuad Journal of Public and International Law (AJPIL) p. 214.

[56] Convention on the Right of the Child (CRC) Article 1, African Charter on the Right and Welfare of the Child CFRN 1999, Child Right Act 2003, Child Labour (Provision Regulation Act, 1986).

[57] Section 341999 Constitution (as amended).

[58] https://doi.org/10.1542/peds2018-2585 accessed in May 2020.

[59] https://reliefweb.int>report>nigeria.

[60] I O Babatunde \& T J Omidoyin Domestic Terrorism and the Application of International Humanitarian Law in Protecting Internally Displaced the Nigeria Law Journal vol. 20, No. 1, p. 138.

[61] B Ogwo Terrorism Act in Nigeria: An Appraisal, University of Jos Law Journal Vo.10, No 1, 2015.

[62] Declaration on the Protection of Women and Children in Emergency and Armed Conflict, Proclaimed-by General Assembly Resolution 3318 (xxix) of 14 December 1974.

[63] Ibid Article 1.

[64] Ibid Article 4.

[65] (2004) IINWLR 193.

[66] Supra.

[67] (2014) vol. 284 LRCN p. I at pp.26k J.J-27A.

[68] 1999 Constitution (as amended).

[69] (2014) vol.234 LRCN p. 34 at 65 FP.

[70] (2003) 8 NWLR (pt. 823) 580-part H.

[71] C Arinze Umeobi op.cit.

[72] Ibid.

[73] (1972), 105 CI, (1973) INML, 25.

[74] Okpanum v Okpanum (1972) 2E CSLR 561.

[75] international Convention for the Suppression of the Traffic in Women and Children (1921), Convention for the Suppression of the Traffic in Persons and Exploitation of the Prostitution of Others (1949), African Charter on the Rights and Welfare of the Child (1990), Hague Convention on the Civil Aspects of International Child Abduction (1996), Optional Protocol to the Convention on Children, Child Prostitution, and Child Pornography (2000).

[76] Attorney General of Nigeria v Christy Egbule (Unreported) Suit No. $\mathrm{FHC} / \mathrm{S} / 29 \mathrm{C} / 2008)$.

[77] Unreported) charge No. B/17C/2005 judgment was delivered 19th April 2007.

[78] Suit No B/15C/2004 (Unreported) Judgment delivered 19th November 2004. See also the case of another female accused charged for trafficking women and girls out of Nigeria for the exploitation of their Prostitution. Federal Republic of Nigeria $\mathrm{v}$ favor Anware Okwnede (Alias Jemila Adanu Charge No. FHC ASB/24C/09 before Hon. Justice Marcel Awokulehin Judgment was delivered 28th September 2009. 